\title{
Modulating Effects of Posttraining Epinephrine on Memory: Involvement of the Amygdala Noradrenergic System
}

\author{
K.C. LIANG ${ }^{2}$, RONALD G. JULER ${ }^{1}$ and JAMES L. McGAUGH ${ }^{1}$ \\ ${ }^{\prime}$ Center for the Neurobiology of Learning and Memory and Department of Psychobiology, University of California, Irvine, \\ CA, 92717 (U.S.A.) and ${ }^{2}$ Department of Psychology, The National Taiwan University, Taipei, 107 (Taiwan)
}

(Accepted July 23rd, 1985)

Key words: amygdala — epinephrine - inhibitory avoidance - memory — norepinephrine - propranolol — retention

\begin{abstract}
These experiments examined the effects, on retention, of posttraining intra-amygdala administration of norepinephrine (NE), and propranolol. Rats were trained on a one-trial step-through inhibitory avoidance task and tested for retention $24 \mathrm{~h}$ later. Injections were administered bilaterally $(1.0 \mu \mathrm{l} /$ injection) through chronically-implanted cannulae. Low doses of $\mathrm{NE}(0.1 \mathrm{or} 0.3 \mu \mathrm{g})$ administered shortly after training enhanced retention while higher doses $(1.0$ or $5.0 \mu \mathrm{g})$ were ineffective. Retention was not affected by NE administered $3 \mathrm{~h}$ after training. The effect of intra-amygdala $\mathrm{NE}$ on retention is blocked by simultaneous administration of propranolol ( 0.2 $\mu \mathrm{g}$ ). This finding suggests that the memory-enhancing effect of NE may be mediated by $\beta$-receptors. Posttraining intra-amygdala NE also attenuated the retention deficit produced by adrenal demedullation. Further, intra-amygdala injections of propranolol ( $0.2 \mu \mathrm{g}$ ) blocked the enhancing effect, on retention, of posttraining s.c. injections of epinephrine. These findings suggest that activation of noradrenergic receptors in the amygdala may be involved in memory processing and may play a role in the memory-modulating effect of peripheral epinephrine.
\end{abstract}

\section{INTRODUCTION}

There is extensive evidence suggesting that the amygdala may be involved in modulating memory storage. It is well-known that, in rats, retention of various types of learning tasks is impaired by posttraining sub-seizure electrical stimulation of the amygdala 14,23 . The amnesic effect of posttraining amygdala stimulation is blocked in animals with lesions of the stria terminalis, a major amygdala afferent-efferent pathway ${ }^{16}$. Further, memory is impaired by posttraining bilateral lesions of the amygdala if the lesions are made within two days following training ${ }^{19}$. Such findings suggest that the amygdala may influence memory through modulating influences on other brain systems involved in the storage of information and are consistent with other evidence suggesting that it is unlikely that the amygdala is involved as a site of memory storage. Studies of the human patient H.M., for example, clearly indicate that bilateral removal of the amygdala and hippocampus produce a form of anterograde amnesia without impairing well-established memories ${ }^{24}$. Comparable findings have been obtained in recent studies with monkeys 25.29 .

Other recent findings indicate that in rats, retention in inhibitory avoidance tasks is also affected by posttraining alterations of opioid and adrenergic systems in the amygdala. Posttraining intra-amygdala injections of the opiate agonist levorphanol produced a naloxone-reversible retention deficit ${ }^{2,13}$. Retention is also impaired by posttraining intra-amygdala injections of the $\beta$-noradrenergic blockers, propranolol or alprenolol. The retention impairment effect is time-dependent, and receptor stereo-specific and is attenuated by intra-amygdala administration of NE ${ }^{11}$. Other findings of Gallagher and Kapp ${ }^{10}$ indicated that retention of an inhibitory avoidance response is enhanced by posttraining intra-amygdala injections of the $\alpha$-noradrenergic antagonist. phentol-

Correspondence: J.L. McGaugh, Center for the Neurobiology of Learning and Memory, University of California. Irvine, CA 92717 . U.S.A. 
amine. The effect of phentolamine was blocked by propranolol" $"$. Gallagher and Kapp ${ }^{\prime \prime}$ interpreted these findings as suggesting that phentolamine may enhance retention by blocking feedback-inhibition of $\mathrm{NE}$ release.

If. as these findings suggest, retention is enhanced by the release of intra-amygdala norepinephrine (NE), it should be possible to enhance retention with posttraining intra-amygdala administration of $\mathrm{NE}$. The evidence, to date, does not support this implication. On the contrary, Kesner and his colleagues ${ }^{t-8.15}$ have reported that posttraining intra-amygdala injections of $1.0 \mu \mathrm{g} \mathrm{NE}$ impair inhibitory avoidance retention. While these results provide further support for the view that noradrenergic stimulation within the amygdala may be involved in memory modulation, they appear to conflict with the findings of Gallagher et al. 10.11 . The present studies were conducted to clarify this issue. Since it is well-known that inverted$\mathrm{U}$ dose-response effects are typically obtained in studies of drug and hormonal effects on memory 21.22 experiments in the present study investigated the dose-response effects of posttraining intra-amygdala administration of NE on retention of an inhibitory avoidance response, using doses of NE lower than those used in previous studies.

Previous evidence has suggested that various hormones released into peripheral circulation may act as endogenous memory modulators ${ }^{22}$. Recent findings from our laboratory suggest that the influences of epinephrine (E) on memory may involve the amygdala. We have found that while posttraining electrical stimulation of the amygdala impairs retention in rats with intact adrenals, amygdala stimulation enhances retention in adrenal demedullated (ADMX) or denervated (ADNX) rats ${ }^{1}$. However, if ADMX rats are given systemic injections of $\mathrm{E}$ shortly prior to the amygdala stimulation, the stimulation produces a retention deficit as profound as that seen in animals with intact adrenals ${ }^{18}$. Further, lesions of the stria terminalis block the effect of peripheral $\mathrm{E}$ on memory ${ }^{17}$. These findings suggest that the effect of peripheral $\mathrm{E}$ on memory may depend upon the functional integrity of the amygdala system, or more specifically, that the influences of peripheral $\mathrm{E}$ on memory may be mediated through influences involving the amygdala. If the effects are based on adrenergic activation of the amygdala, intra-amygdala adminis- tration of NE might be expected to attenuate retention deficits seen in adrenal-demedullated rats Further, the memory-enhancing effects of peripherallyadministered $E$ should be blocked by intra-amygdala injections of propranolol. Experiments in the present study were designed to address this question

\section{MATERIALS AND METHODS}

\section{Subjects}

Male Sprague-Dawley rats $(60-70$ days old, 250-300 g) were individually housed upon arrival and maintained on a 12/12 light-dark cycle (lights on at $07.00 \mathrm{~h}$ ) with food and water ad libitum. A total of 297 rats was used in the present study.

\section{Surgery}

Amygdala cannula implantation. Approximately one week after arrival, all rats were subjected to stereotaxic brain surgery. Under sodium pentobarbital $(50 \mathrm{mg} / \mathrm{kg})$ anesthesia, 23-gauge stainless-steel thinwall cannulae ( $15 \mathrm{~mm}$ long) were implanted bilaterally into the amygdala. The tips were aimed at the dorsal surface of the amygdala complex (A.P. $-1.0 \mathrm{~mm}$ from bregma, M.L. $\pm 4.3 \mathrm{~mm}$ from midline, D.V. $-5.5 \mathrm{~mm}$ below dura, with the nosebar at $5.0 \mathrm{~mm}$ above the interaural line). Two cortical screws serving as anchors were implanted over the right frontal and left posterior cortices. The cannulae were fixed on the skull with dental cement. A stylet (made from 00 insect pins) was inserted into each cannula to maintain patency.

Adrenal demedullation. In experiment III, rats received sham or adrenal demedullation two weeks following the cannula implantation. They were anesthetized as described above. Bilateral incisions were made on the dorsal surface of the body wall behind the last rib. The adrenal gland was exposed and the medulla tissue was removed with microdissecting scissors. The sham adrenal operation followed the same procedure except that the medulla was not removed. Our previous findings ${ }^{1}$ indicate that this demedullation procedure results in greater than $95 \%$ depletion of adrenal catecholamines. At the conclusion of each surgery the rats received an intra-muscular injection of bicillin (5000 IU). They were maintained on tetracycline water (with $0.9 \% \mathrm{NaCl}$ added for the demedullated rats) for one week following the 
surgery. The $\mathrm{NaCl}$ was added to protect against possible adrenal cortex damage produced by the adrenal demedullation surgery.

\section{Behavioral task}

Two weeks after the second surgery the rats were trained on a one-trial step-through avoidance task ${ }^{16}$. The apparatus consisted of a trough-shape alley divided by a sliding door into an illuminated safe compartment and a dark shock compartment. The rat was placed into the safe compartment facing away from the door. As the rat turned toward the door, the door was opened. As the rat entered the dark compartment, the door was closed and a 1-s footshock was administered. The shock intensity, measured as the root-mean-square of sinusoidal currents, was set at $0.7 \mathrm{~mA}$ except when otherwise noted. The rat was removed from the alley about $5 \mathrm{~s}$ after receiving the shock, administered the posttraining treatments and placed back into the home cage. On the retention test given 24 h later, the rat was placed into the illuminated compartment as on the training trial and the latency to enter the dark compartment was recorded as a measure of retention performance. Rats which did not enter the dark compartment within $600 \mathrm{~s}$ were removed from the alley and assigned a ceiling score of 600 .

\section{Intra-amygdala drug administration}

The injections were administered through a 30-gauge injection needle connected to a $10 \mu \mathrm{l} \mathrm{Ham-}$ ilton microsyringe by a $1-\mathrm{m}$ polyethylene tubing (PE20). The 30-gauge needle was bent at a length such that, when inserted into the cannula, the needle tip protruded $1.5 \mathrm{~mm}$ into the brain tissue. Both the microsyringe and the PE tubing were filled with drug solutions. Immediately after training, the stylets were withdrawn from the cannulae, and injection needles were inserted. One microliter of the drug solution was delivered into each amygdala through the microsyringe over a period of 45-60 s. The two amygdalae were injected sequentially. The injection needles were withdrawn from the cannulae about $10-15 \mathrm{~s}$ after termination of the injection and the stylets were immediately replaced. All drugs were dissolved into a special buffered solution ${ }^{6}$, which in $100 \mathrm{ml}$, contained $0.9 \mathrm{~g}$ of $\mathrm{NaCl}, 4.05 \mathrm{ml}$ of $0.2 \mathrm{M} \mathrm{Na}_{2} \mathrm{HPO}_{4}$ and $0.95 \mathrm{ml}$ of $0.2 \mathrm{M} \mathrm{NaH}_{2} \mathrm{PO}_{4} \cdot \mathrm{H}_{2} \mathrm{O}$.

\section{Histology}

At the conclusion of each experiment, the rats were sacrificed with an overdose of sodium pentobarbital and were perfused through the heart with $0.9 \%$ saline followed by $10 \%$ formalin. During perfusion, the intra-amygdala injection needles were inserted in the cannulae in order to mark the tips in the brain tissue. The brain was then removed, stored in formalin for at least $48 \mathrm{~h}$, and sectioned. The sectioned slices ( $40 \mu \mathrm{m}$ ) through the cannula and needle tracts were examined after cresyl violet staining. Behavioral data from animals in which the needle tips missed the amygdala complex were excluded from the final analysis. A total of 27 animals were discarded for this reason. The number of rats included in each group is indicated in the figures and tables.

\section{EXPERIMENT I}

The first experiment examined dose-response effects of posttraining intra-amygdala in jections of NE on retention. In view of the retention deficit observed by Ellis and Kesner ${ }^{7}$ in an experiment using a relatively high training footshock $(3 \mathrm{~mA} / 3 \mathrm{~s})$, as well as evidence that the effects of posttraining treatments vary with the training conditions, we used relatively low footshock intensity $(0.7 \mathrm{~mA} / 1 \mathrm{~s})$.

\section{Procedure}

Implanted rats were trained as described in the Methods section. Immediately after training, they received bilateral intra-amygdala injections of vehicle (Veh) or one of the following doses of NE: $0.1,0.3$, 1.0 or $5.0 \mu \mathrm{g}$. Retention was tested $24 \mathrm{~h}$ later.

\section{Results}

Retention performance is shown in Fig. 1. Since the distribution of retention scores was truncated at $600 \mathrm{~s}$, non-parametric statistics were used to analyze the data throughout this study.

A Kruskal-Wallis one-way analysis of variance indicated significant differences among the groups ( $\mathrm{H}=16.86, P<0.005)$. Two-tailed Mann-Whitney U-tests indicated that the retention performance of groups receiving 0.1 or $0.3 \mu \mathrm{g} \mathrm{NE}$ was significantly better than that of the Veh-injected controls $(0.1 \mu \mathrm{g}$ NE vs Veh, $U=14, P<0.002 ; 0.3 \mu$ g NE vs Veh, $U$ $=44.5, P<0.01)$. The retention latencies of the 


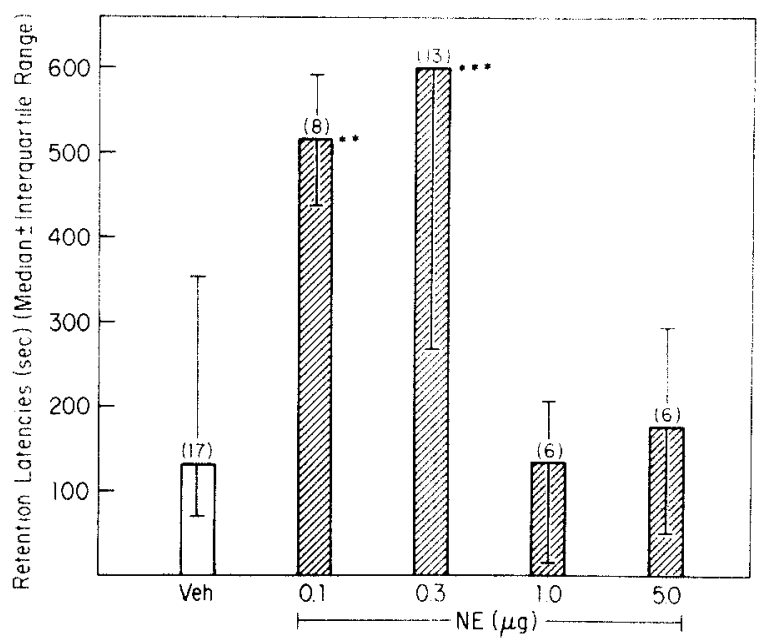

Fig. 1. Effects of intra-amygdala injections of various doses of $\mathrm{NE}$ on inhibitory avoidance retention. ${ }^{* * *} P<0.002$ : $^{* *} P<$ (1.01, different from the Veh group.

groups given 1.0 or $5.0 \mu \mathrm{g}$ NE were not statistically different from those of the Veh-injected group. Further, the retention latencies of both of the higher dose groups were lower than those of the lower dose groups $(1.0 \mu \mathrm{g} \mathrm{NE}$ vs 0.1 or $0.3 \mu \mathrm{g} \mathrm{NE}, \mathrm{U}=0$ and 9 , $P<0.02 ; 5.0 \mu \mathrm{g} \mathrm{NE}$ vs 0.1 or $0.3 \mu \mathrm{g} \mathrm{NE}, \mathrm{U}=4$ and 14. $P<0.05)$.

\section{EXPERIMENT II}

The results of experiment $I$ indicated that posttraining intra-amygdala injections of NE produced dose-dependent facilitation of retention in an inhibitory avoidance task. In experiment II, we examined the effects on retention of immediate and delayed posttraining intra-amygdala injections of NE. If the $\mathrm{NE}$ affects memory through influences on posttraining processes involved in memory storage, the delayed injections should not affect retention. Further, to evaluate the possible punitive effect of intra-amygdala NE injections, immediate posttraining injections of Veh or NE were administered to two groups of rats which were not given footshock in the training. Previous findings ${ }^{27}$, indicate that both $\alpha$ - and $\beta$ receptors are present in the amygdala. In an attempt to determine whether the NE effects on memory are due to influences on $\beta$-receptors we examined the effects of concurrent posttraining administration of NE and the $\beta$-antagonist, propranolol.

\section{Procedure}

The rats were trained as described in the Methods section. Immediately after training, the animals received intra-amygdala injections of one of the following treatments: Veh, $0.2 \mu \mathrm{g} \mathrm{NE}, 0.2 \mu \mathrm{g} \mathrm{NE}$ plus 0.2 $\mu \mathrm{g}$ propranolol (Prop), $0.2 \mu \mathrm{g}$ NE plus $1.0 \mu \mathrm{g}$ Prop. An additional group was given intra-amygdala injections of $0.2 \mu \mathrm{g} \mathrm{NE} 3 \mathrm{~h}$ after training. Two groups of animals were placed in the apparatus and allowed to step into the dark compartment without receiving footshock. Immediately after training. they received intra-amygdala injections of Veh, or NE. When NE and propranolol were given simultaneously, they were dissolved in the same solution.

\section{Results}

As shown in Table I, the latencies of the animals which were not given footshock were significantly lower than those of the corresponding footshock animals ( $\mathrm{U}=9$ and 5 respectively for the Veh and NE groups, $P<0.002$ ). Posttraining intra-amygdala NE did not affect the no-footshock groups.

A Kruskal-Wallis one-way analysis of variance indicated that there were significant differences among the Veh group, the immediate NE group and the delayed NE group $(\mathrm{H}=9.75, P<0.01)$. Two-tailed Mann-Whitney U-tests indicated that the group receiving immediate posttraining NE injections had better retention performance than that of either the Veh-injected group or the group given delayed posttraining injections of NE (immediate NE vs Veh, $\mathrm{U}=79.5, P<0.01 ;$ immediate $\mathrm{NE}$ vs delayed $\mathrm{NE}$, $\mathrm{U}=19, P<0.02$ ).

There were also significant differences among the

\section{TABLE I}

Effects of posttraining intra-amygdala administration of norepinephrine (NE) and propranolol on inhibitory avoidance retention

\section{Treatments}

Veh

Veh (noFS)

NE $0.2 \mu \mathrm{g}$ immediate

NE $0.2 \mu \mathrm{g}$ immediate (no FS)

NE $0.2 \mu \mathrm{g}$ delayed

NE $0.2 \mu \mathrm{g}+$ propranolol $0.2 \mu \mathrm{g}$

NE $0.2 \mu \mathrm{g}+$ propranolol $1.0 \mu \mathrm{g}$ 
immediate NE group, the NE plus $0.2 \mu \mathrm{g}$ Prop groups and the NE plus $1.0 \mu \mathrm{g}$ Prop group $(\mathrm{H}=6.04, P<$ 0.05). Two-tailed Mann-Whitney U-tests indicated that retention latencies of the NE plus $0.2 \mu \mathrm{g}$ Prop group were significantly lower than those of the immediate NE group ( $\mathrm{U}=49.5, P<0.01)$. While the group receiving NE plus $1.0 \mu \mathrm{g}$ Prop injections also had lower retention latencies than those of the group given immediate $\mathrm{NE}$ injections, the difference was not statistically significant.

\section{EXPERIMENT III}

The findings of experiment II indicated that $0.2 \mu \mathrm{g}$ of NE injected into the amygdala immediately after training improved retention, whereas an injection of $\mathrm{NE}$ given $3 \mathrm{~h}$ later had no effect. These findings support the view that the NE enhanced retention by influencing time-dependent memory storage processes. The results also indicated that propranolol administered in the same solution with NE attenuated the effect of NE on retention. These findings suggest that enhancing of intra-amygdala NE may be due, at least in part, to activation of the noradrenergic $\beta$-receptors.

Previous evidence has shown that adrenal demedullation produces a retention deficit, and the deficit is attenuated by posttraining injection of $E^{3,18}$. If peripheral $E$ affects memory through releasing $N E$ in

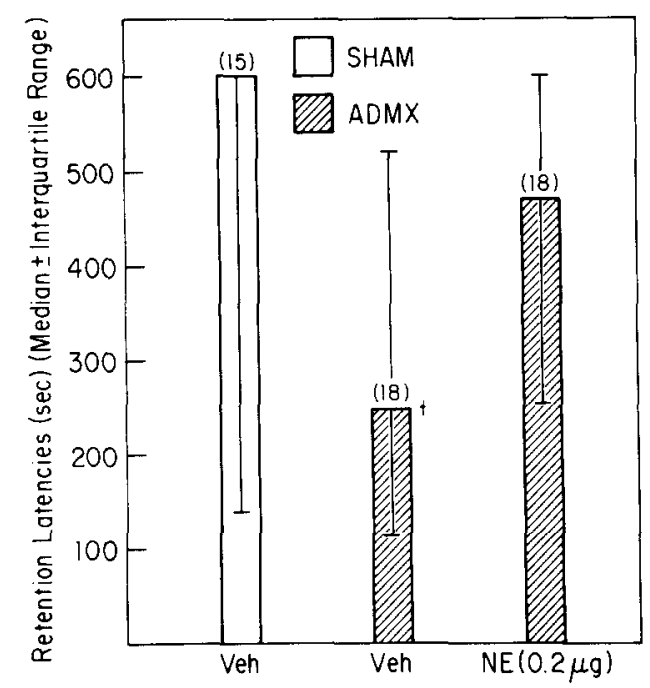

Fig. 2. Effects of intra-amygdala NE injections on retention performance of ADMX rats. ${ }^{+}$Different from the Veh/Sham and the NE/ADMX group, $P<0.05$. the amygdala as proposed above, it should be possible to attenuate the retention deficit produced by adrenal demedullation by injecting NE into the amygdala. To examine this possibility, experiment III investigated the effect of intra-amygdala NE injections on retention performance of ADMX rats.

\section{Procedure}

One group of adrenal sham-operated rats (Sham) and two groups of ADMX rats were trained as described in the Methods section except that the training footshock intensity was increased to $1 \mathrm{~mA}(1 \mathrm{~s})$. This footshock level was selected on the basis of our previous studies of inhibitory avoidance in demedullated rats with amygdala implants ${ }^{1.18}$. Immediately after training, the Sham group and one of the ADMX groups received intra-amygdala injections of $0.2 \mu \mathrm{g}$ NE.

\section{RESULTS}

The $24 \mathrm{~h}$ retention performance of the 3 groups is shown in Fig. 2. A Kruskal-Wallis one-way analysis of variance indicated significant differences among the 3 groups $(\mathrm{H}=6.289, P<0.05)$. Two-tailed MannWhitney U-tests indicated that adrenal demedullation, as found in previous studies, impaired retention in the Veh-injected rats: the ADMX/Veh group had significantly poorer retention than the Sham/Veh group $(U=73, P<0.05)$. Posttraining administration of NE-attenuated the retention deficit, the retention latencies of the ADMX/NE groups were significantly higher than those of the ADMX/Veh group $(\mathrm{U}=98, P<0.05)$. While the retention scores of the ADMX/NE group did not reach the level of the Sham/Veh group, the difference between the two was not statistically significant.

\section{EXPERIMENT IV}

Results of experiment III indicated that posttraining intra-amygdala injections of NE attenuated the retention deficit induced by adrenal demedullation. These results are consistent with a view that activation of the noradrenergic receptors in the amygdala may be involved in the effect, on retention, of peripherally administered $\mathrm{E}$. According to this view, blocking the noradrenergic receptors in the amygdala 


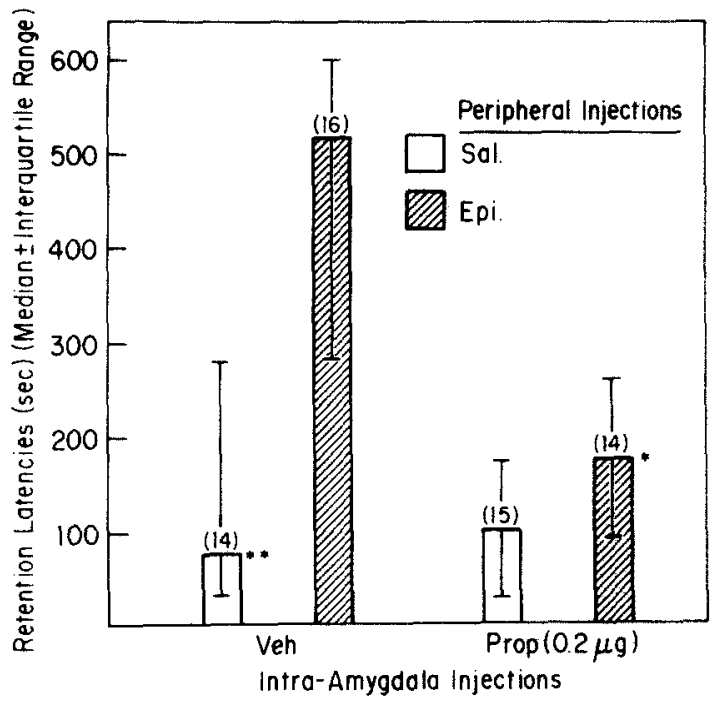

Fig. 3. Effects of intra-amygdala propranolol and peripheral $E$ on inhibitory avoidance retention. ** Different from the Veh/E group, $P<0.02{ }^{*}$ Different from the Veh/E group, $P$ $<0.05$.

should attenuate the effect on retention of peripherally administered E. Experiment IV was designed to address this question.

\section{Procedure}

Four groups of rats were trained as described in the Methods section. Immediately after training, animals in two of the groups received intra-amygdala injections of Veh, while animals in the other two groups received intra-amygdala injections of $0.2 \mu \mathrm{g}$ Prop. Immediately following the intra-amygdala treatment, one of each of the above groups received a subcutaneous (s.c.) injection of saline (Sal) and the remaining group received a s.c. injection of $\mathrm{E}(0.1$ $\mathrm{mg} / \mathrm{kg}$ in $0.1 \mathrm{mg} / \mathrm{cc}$ solution). E was prepared directly from a $1.0 \mathrm{mg} / \mathrm{cc}$ solution (Elkins-Sinn) containing $0.1 \%$ sodium bisulfite.

\section{Results}

The $24 \mathrm{~h}$ retention performance is shown in Fig. 3. In rats given intra-amygdala injections of Veh, s.c. administration of $E$ enhanced retention: the retention performance of the Veh/E group was better than that of the $\mathrm{Veh} / \mathrm{Sal}$ group $(\mathrm{U}=42, P<0.01)$. In contrast, s.c. administration of $E$ did not affect retention of rats given intra-amygdala injections of propranolol: no significant difference was found between the Prop/Sal group and the Prop/E group. Further, the retention performance of the Prop/E group was significantly poorer than that of the Veh/E group $(\mathrm{U}=52, P<0.02)$.

\section{Histology}

The location of the injection needles is shown in Fig. 4. The central, basolateral and basomedial nuclei had a higher density of tips than other nuclei in the amygdala. However, retention scores did not differ as a function of injection site within the amygdala.

\section{DISCUSSION}

There are 4 major findings of these studies. First, the findings indicate that retention of an inhibitory avoidance response is enhanced by posttraining intra-amygdala injections of NE. Second, the enhancing effect of posttraining NE is attenuated by concurrent administration of propranolol. Third, posttraining intra-amygdala administration of NE attenuated the retention deficit produced by adrenal demedullation. And fourth, intra-amygdala administration of propranolol blocked the enhancing effect of peripherally administered epinephrine.

Since all of the injections were administered shortly after training, the effects of the treatments cannot be attributed to influences on processes involved in acquisition. Further, since NE did not affect retention when administered $3 \mathrm{~h}$ after training. it seems unlikely that the immediate posttrial injections affected retention performance because of residual effects $24 \mathrm{~h}$ after the injection. The finding that posttraining did not affect retention performance unless the animals received a footshock on the training trial argues that the effects of posttraining NE on retention performance are not due to an aversive effect of the NE. Thus, the findings are consistent with the view that adrenergic agonists enhance retention through influences on memory consolidation processes.

In the dose used in the present study, propranolol did not affect retention when given alone. Previous findings 11 indicate that retention is impaired by high doses of propranolol (34.0 and $17.0 \mathrm{nM}$ ) administered to the amygdala after training. A lower dose ( $8.5 \mathrm{nM}$ ) was ineffective. Our dose, $0.2 \mu \mathrm{g}$, is approximately $0.77 \mathrm{nM}$, which is less than $10 \%$ of the lowest dose used by Gallagher et al. ${ }^{11}$. Thus, it seems likely 


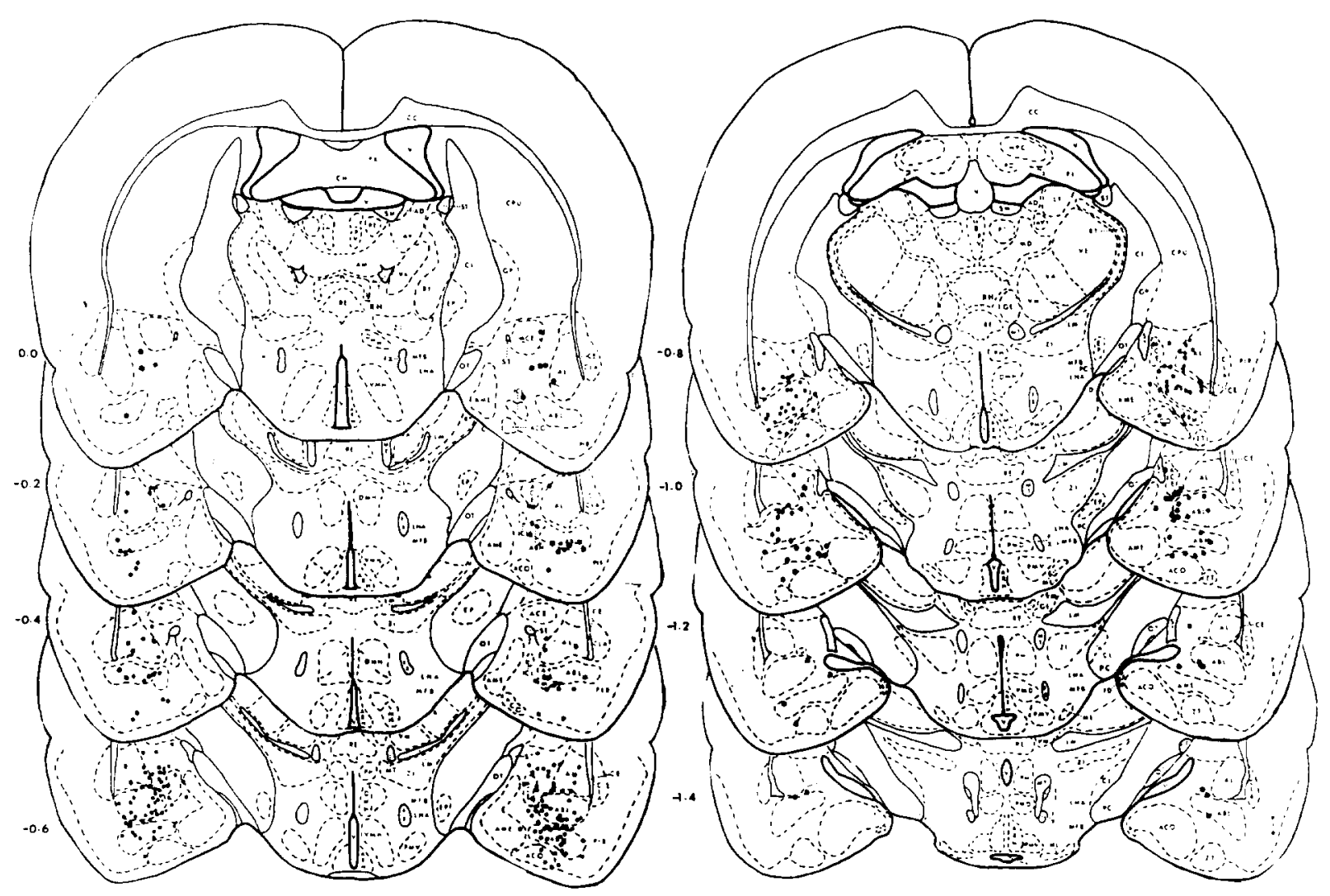

Fig. 4. Distribution of injection needle tips: $0.0=$ Bregma. The width of the dots is approximately one-third of the diameter of the injection needle. The implanted cannulae penetrated to the border of the caudate-putamen and amygdaloid complex.

that the attenuating effects of propranolol on the retention enhancement produced by NE is due to specific antagonism of NE rather than a general impairing effect. Previous research has also shown that retention is impaired by posttraining intra-amygdala injections of NE? . The dose used in that study $(1.0 \mu \mathrm{g})$ was higher than the doses found to facilitate retention in the present experiments $(0.1-0.3 \mu \mathrm{g})$. Ellis and $\mathrm{Kesner}^{7}$ also used a higher training footshock intensity $(3 \mathrm{~mA} / 3 \mathrm{~s})$ than that used in the present experiments $(0.7 \mathrm{~mA} / 1 \mathrm{~s})$. Numerous previous studies have shown that enhancement of retention is more likely to be obtained with low footshock and with low doses of drugs or hormones while retention impairment is typically found with high training footshock and higher doses of drugs and hormones ${ }^{21.22}$. In our experiments the animals were maintained with food and water ad libitum while the rats in the Ellis and Kesner $^{7}$ study were water-deprived. In view of evidence that water-deprivation may alter brain NE metabolism ${ }^{19}$, it may be that intra-amygdala injections of NE produce different effects in water-deprived and non-deprived animals.

The tips of the injection needles were located primarily in the central, lateral, basolateral, and basomedial nuclei of the amygdala. While Gallagher et al. ${ }^{13}$ reported that the central amygdaloid nucleus was the most effective site for adrenergic influences on memory we found no differential effects among the various injection sites within the amygdala. Noradrenergic projections from the locus coeruleus and some nuclei in the medulla innervate the central, lateral, and basal amygdaloid nuclei ${ }^{9}$. Thus, our findings are consistent with the interpretation that adrenergic agonists and antagonists injected into the amygdala modulate memory processing by acting on receptors in the amygdala. While we cannot rule out the possibility that the effects are due to diffusion of injected solutions to other regions adjacent to the amygdala, previous evidence ${ }^{7}$ indicates that $\mathrm{NE}$ injections administered to the caudate do not affect retention. Additional experiments are needed to deter- 
mine whether noradrenergic modulation of memory is unique to the amygdala.

A major question addressed by these experiments was whether the effects of peripheral epinephrine on retention are mediated by adrenergic influences in the amygdala. Previous studies have shown that the impaired retention seen in adrenal-demedullated rats is attenuated by peripheral injections of epinephrine 3.18 . Findings of the present study indicate that the retention deficit in ADMX rats is also attenuated by posttraining intra-amygdala injections of $\mathrm{NE}$. This finding is consistent with the interpretation that peripheral epinephrine affects retention through adrenergic stimulation of the amygdala. It might be that peripherally released or administered epinephrine directly or indirectly activates adrenergic receptors in the amygdala. Alternatively, activation of adrenergic receptors in the amygdala resulting from training experiences may initiate amygdala activity which produces effects elsewhere in the brain which interact with effects of epinephrine in modulating memory storage. This latter interpretation, is, however, not consistent with our finding that intra-amygdala NE enhances retention in adrenal-demedullated rats.

\section{REFERENCES}

1 Bennett, C., Liang, K.C. and McGaugh, J.L., Depletion of adrenal catecholamines alters the amnestic effects of amygdala stimulation, Behav. Brain Res., 15 (1985) 83-91.

2 Baust, W., Niemczyk, H. and Vieth, J., The action of blood pressure on the ascending reticular activating system with special reference to adrenaline induced EEG arousal, Electroencephalogr. Clin. Neurophysiol., 15 (1963) 63-72.

3 Borrell, J., de Kloet, E.R., Versteeg, D.H.G. and Bohus, B., Inhibitory avoidance deficit following short-term adrenalectomy in the rat: the role of adrenal catecholamines, Behav. Neural Biol., 39 (1983) 241-258.

4 Dahlgren, N., Rosen, I., Sakabe, T. and Siesjo. R.K., Cerebral functional, metabolic and circulatory effects of intravenous infusion of adrenalin in rat, Brain Research, 184 (1980) 143-152.

5 Dell, P. and Olson, R., Projections 'secondairies' mesencephaliques diencephaliques et amygdaliennes des afferences visceralis vagales, C.R. Soc. Biol., 145 (1951) $1088-1091$

6 Ellis, M.E. and Kesner, R.P., Physostigmine and norepinephrine: effects of injection into the amygdala on taste association, Physiol. Behav., 26 (1981) 203-209.

7 Ellis, M.E. and Kesner, R.P.. The noradrenergic system of the amygdala and aversive memory processing. Behav. Neurosci., 97 (1983) 399-415.
Since it is generally assumed that epmephrince doc not cross the blood-brain barrier $2 x$. it is not clear how peripheral epinephrine acts to influence central NF. It may be that small amounts of epinephrine leak into brain regions poorly protected by the blood-bram barrier. Or, it may be that epinephrine affects brain functions by altering blood flow or regional metabolism ${ }^{4}$. Alternatively, peripheral epinephrine might activate centripedal visceral afferents which terminate on brainstem catecholaminergic nuclei2t. Peripheral visceral stimulation is known to activate the reticular formation ${ }^{2}$ and to induce evoked potentials in the amygdala ${ }^{5}$. Thus, peripheral epinephrine might regulate amygdala noradrenergic activity either indirectly, through influences on brainstem noradrenergic nuclei or directly, by stimulating noradrenergic receptors in the amygdala. At present we cannot distinguish among these alternatives.

\section{ACKNOWLEDGEMENTS}

Supported by USPHS Research Grants MH 12526 and $A G 00538$ and Research Contract N00014-84-K0391 from the Office of Naval Research to J.L. McG.

8 Ellis, M.E., Berman, R.F. and Kesner, R.P., Amnesia attenuation specificity: propranolol reverses norepinephrine but not cycloheximide-induced amnesia, Pharmacol. Biochem. Behav., 19 (1983) 733-736.

9 Fallon, J.H., Histochemical characterization of dopaminergic noradrenergic and serotonergic projections of the amygdala. In Y. Ben-Ari (Ed.), The Amygdaloid Complex, Elsevier, Amsterdam, 1981, pp. 175-183.

10 Gallagher, M. and Kapp, B.S., Effect of phentolamine administration into the amygdala complex of rats on time-dependent memory processes, Behav. Neural Biol., 31 (1981) 90-95.

11 Gallagher, M. Kapp, B.S. Musty, R.E. and Driscoll, P.A.. Memory formation: evidence for a specific neurochemical system in the amygdala, Science, 198 (1977) $423-425$.

12 Gallagher, M. and Kapp. B.S., Manipulation of opiate activity in the amygdala alters memory processes. Life $S_{c i}$, 23 (1978) 1973-1978.

13 Gallagher, M., Kapp, B.S., Pascoe. J.P. and Rapp, P.R., A neuropharmacology of amygdala systems which contribute to learning and memory. In Y. Ben-Ari (Ed.), The Amygdaloid Complex, Elsevier, Amsterdam, 1981, pp. 343-354.

14 Kesner, R.P., Brain stimulation: effects on memory, $B e$ hav. Neural Biol., 36 (1982) 315-367.

15 Kesner, R.P. and Ellis, M.E., Memory consolidation: brain 
region and neurotransmitter specificity, Neurosci. Lett., 39 (1983) 295-300.

16 Liang, K.C. and McGaugh, J.L., Lesions of the stria terminalis attenuate the amnestic effect of amygdaloid stimulation on avoidance responses, Brain Research, 9 (1983) $49-58$.

17 Liang, K.C. and McGaugh, J.L., Lesions of the stria terminalis attenuate the enhancing effect of post-training epinephrine on retention of an inhibitory avoidance response, Behav. Brain Res., 9 (1983) 49-58.

18 Liang, K.C., Bennett, C. and McGaugh, J.L., Peripheral epinephrine alters the effect of amygdaloid stimulation on retention, Behav. Brain Res., 15 (1985) 93-100.

19 Liang, K.C., McGaugh, J.L., Martinez, Jr., J.L., Jensen, R.A., Vasquez, B.J. and Messing, R.B., Posttraining amygdaloid lesions impair retention of an inhibitory avoidance response, Behav. Brain Res., 4 (1982) 237-249.

20 Luttinger, D. and Seiden, L.S., Increased hypothalamic norepinephrine metabolism after water deprivation in the rat, Brain Research, 208 (1981) 147-165.

21 McGaugh, J.L., Drug facilitation of learning and memory. Annu. Rev. Pharmacol., 13 (1973) 229-241.

22 McGaugh, J.L., Hormonal influences on memory, Ann. Rev. Psychol., 27 (1983) 297-323.

23 McGaugh, J.L. and Gold, P.E., Modulation of memory by electrical stimulation by the brain. In M.R. Rosenzweig and E.L. Bennett (Eds.), Neural Mechanisms of Learning and Memory, MIT Press, Cambridge, MA, 1976, pp. 549-560.

24 Milner, B., Amnesia following operation on the temporal lobes. In C.W.M. Whittney and O.L. Zangwill (Eds.), Amnesia, Butterworths, London, 1966, pp. 109-133.

25 Mishkin, M., Malamut, B. and Bachevalier, J.. Memories and habits: two neural systems. In G. Lynch, J.L. McGaugh and N.M. Weinberger (Eds.), Neurobiology of Learning and Memory, Guilford Press, New York, 1984. pp. 65-77.

26 Summal, K.K., Blessing, W.W., Joh, T.H., Reis, D.J. and Pickel, V.M., Ultrastructural evidence that vagal afferents terminate on catecholaminergic neurons in the nucleus tractus solitarius, Soc. Neurosci. Abstr., 8(1982) 429.

27 U'Prichard, D.C., Reisine, T.D., Masion, S.F., Fibiger, H.C. and Yamamura, H.I. Modulation of rat alpha- and beta-adrenergic receptor populations by lesions of the dorsal noradrenergic bundle, Brain Research, 187 (1980) 143-154.

28 Weil-Malherbe, H., Axelrod, H. and Tomchick, R.. Blood-brain barrier for adrenaline, Science, 129 (1959) 1226-1228.

29 Zola-Morgan, S., Squire, L.R. and Mishkin, M., The neuroanatomy of amnesia: amygdala hippocampus vs. temporal stem, Science, 218 (1982) 1337-1339. 